\title{
EFFECTS OF DIFFERENTIAL TRAINING IN RULE- GOVERNED BEHAVIOR ON COMPLIANCE WITH TRAFFIC RULES BY PEDESTRIANS
}

\author{
Yerly Ruíz-Martínez \\ Paula Hernández-Buitrago \\ Luis Alberto Quiroga-Baquero' \\ Universidad Santo Tomás, Colombia
}

\begin{abstract}
The aim of this translational research was to investigate the effect of differential training in three types of rule-governed behavior (RGB) on compliance and transgression with pedestrian traffic rules. Participants were 231 university students divided in three groups defined by the type of training (pliance, tracking and augmenting). The design consisted of pre-tests and post-tests, in addition of a training phase with direct reinforcement that defined by the group each participant belonged. The results showed a general trend of compliance to the rule in all phases, particularly with tracking-consequences in pre and post-training. In all experimental groups, training in RGB increased compliance of traffic rules. These findings allow the formulation of evidence-based guidelines for the design, implementation and evaluation of road programs to accident prevention.
\end{abstract}

\section{Keywords}

Pedestrian; rule-governed behavior; traffic rules; road prevention; legal psychology.

\section{Resumen \\ El objetivo de esta investigación traslacional fue evaluar el efecto del entrenamiento diferencial en tres tipos de comportamiento gobernado por reglas (CGR), sobre el seguimiento y la transgresión de normas de tránsito peatonales. Participaron 231 universitarios divididos en tres grupos definidos por el tipo de entrenamiento (pliance, tracking y augmenting). El diseño consistía en fases de pre-prueba y pos-prueba, y de entrenamiento con reforzamiento directo según el grupo experimental. Los resultados mostraron una tendencia por el cumplimiento de las normas en todas las fases, particularmente ante consecuencias tipo tracking en las fases de pre-test y post-test. En todos los grupos experimentales, el entrenamiento en CGR promovió el seguimiento de las normas de tránsito para peatones. Estos hallazgos permiten la formulación de algunas pautas basadas en evidencia, para el diseño, ejecución y evaluación de programas de prevención vial. \\ Palabras claves \\ Peatón, conducta gobernada por reglas, normas de tránsito, prevención vial, psicología jurídica.}




\section{EFECTO DEL ENTRENAMIENTO DIFERENCIAL EN CONDUCTA GOBERNADA POR REGLAS SOBRE EL CUMPLIMIENTO DE} NORMAS DE TRÁNSITO EN PEATONES

Walking is the fundamental way of displacement, given it is costless and is accessible for each and all individuals; therefore, everybody has the role of pedestrian in any given moment of day (International Transport Forum [ITF], 2011). According the Organization for Economic Cooperation and Development (OECD), "most of pedestrian injuries and deaths happen in urban areas and according police records, between $70 \%$ and $80 \%$ of such collisions happen with vehicles, while pedestrians are crossing a street" (ITF, 2011, p. 11). For the World Health Organization (WHO, 2013), pedestrians are all the people who go their road by foot or "using other aids such as wheelchairs, walkers, walking stick, skates and skateboards" (p. 3). Thus, pedestrians are the most vulnerable elements in the mobility system given the fact that "they are not inside a shell protecting them" (WHO, 2013), and they represent almost half of the deadly victims due to traffic causes in the world.

In Colombia, figures issued by the Legal Medicine and Forensic Sciences Institute (2018) in data showed during 2017, 6754 people died in traffic accidents, where 1790 of those were pedestrians (26.5\%). Likewise, 7936 pedestrians were injured in traffic accidents from 40114 cases (19.78\%). In order to decrease those numbers, the National Road-Safety Plan (NRSP) 2011-2021 puts together pedestrians and motor-bikers as the first road-vial actors with death due to traffic accidents. The abovementioned plan raised the goal to reduce 50\% mortality associated to traffic accidents during their execution years by communication campaigns, where the principal aim would be "make aware all traffic road-vail actors about the road-safety importance and how develop it through prevention and corrective behaviors" (Ministry of Transport of Colombia, 2015, p. 31).

Furthermore, Law 1503 of 2011 (Congress of the Republic of Colombia, 2011) wanted promote the formation of habits, behaviors and other conducts aimed at road-safety. Article 3 promotes road education in general terms, as educational actions designed at allowing each and all the road-vial actors have a role in the mobility and traffic environment, with perfect harmony between people and their environmental context. Finally, the Human Behavior Strategic Plan contained inside NRSP, presented the need of showing training and road-safety educational programs that are focused in road-vial actors with several target groups. It is important of those programs will be aimed to the responsible institutes for road-safety and several collective groups related, keeping the final objective whereas external collaborator, the academy and the university investigation centers also can contribute to improve the implementation of those road-safety educational programs.

Recognizing that education is constituted as the principal method to reach the preventive effects that traffic campaigns want (Obregón-Biosca, Betanzo-Quezada, Romero-Navarrete, \& Ríos-Nuñez, 2018), it would be important to highlight that for a real transformation caused by education aimed at citizens and in this way is imperative to train political directors and officials about the best strategies to gain an effective road safety. This is not only the political leaders are who have the responsibility of design, implement and monitoring preventive and social intervention programs, because in addition development of educational and preventive views are necessary now of construct and transform the social realities with intervention through civic preventive programs (Biglan, 2016; Zare, Niknami, Heidarnia, \& Hossein-Fallah, 2019).

Thus, it is necessary lay down that communication strategies of preventive plans are grounded in empirical evidences with a trans-disciplinary order about phenomena related with social, linguistic, normative and institutional regulations of human behavior with the aim of issue a higher compliance of rules by subjects (Mockus, Murraín, \& Villa, 2012; Pérez-Almonacid \& Quiroga-Baquero, 2010; Wilson, Hayes, Biglan, \& Embry, 2014). In that way, building Road Safety Programs (RSP) based on academic evidences, would be an ideal mean through which psychology could contribute to the creation of new preventive and citizen intervention resources. This comes not only from an analytic knowledge based formulation, but also from considering the qualities and particularities of the cultural contexts and city mobility iniciatives that aim to decrease of the rate of pedestrian accident with the augment of efficiency in preventive regulations communicated through RSP (Assaily, 2017). 
This progress could be achieved through the translational research work, which is defined as a kind of empirical and theoretical research based on the transference of concepts, principles and methodologies from basic research for its use in applied ways to find the solution for socially valued problems and technological development (Critchfield, 2011; Rendón-Arango \& Quiroga-Baquero, 2017). In that way, Vollmer (2011) proposed three translational research strategies: (a) direct application of theoretical categories and empirical evidences on applied solutions of problems; (b) research under controlled laboratory conditions about applied phenomena, which are translated into manipulable and measurable variables; and (c) replicate lab findings into problem-situations with social character.

Nonetheless, in the context of traffic and road safety, the link between analytic disciplinary knowledge that allows the explanation of explain psychological dimensions of such trans-disciplinary phenomena, and issuing public policies, rules, and prevention and intervention programs in Colombia, seems not visible until 2014 when the Colombian Psychologist Association, recognized the field of traffic psychology and road safety. Additionally it is a fact that the information consolidated for the formulation of RSP, is not usually published in the academy and are postulated from professional knowledge in diverse areas, often related with engineering (Perczek, 2013).

With this proposed in mind in addition with the premise where the psychology have a special interest in human behavior analysis and it modification with direct intervention (Biglan, Zettle, Hayes, \& Barnes-Holmes, 2016); it would be possible underline certain analytic and technological approaches from the fields of Behavior Analysis (e.g., experiential analysis of behavior and applied behavioral analysis, respectively) (Kyonka \& Subramaniam, 2018; Peña-Correal, 2016). Within those, there is the Relational Frame Theory (RFT), which proposes a language and cognition explanation in terms of contingency relations between individual behavior and environment. Particularly, this theory emphasizes that specifically human behavior is characterized by forms to respond in a relational way (respond to a stimulus in terms of another one). Those ways, mainly linguistic forms, could be arbitrarily applicable (for instance, the word equal works to relate two oranges or two cars), and they are learned in the developmental histories of everyone through multiple-exemplar training and contingencies of reinforcement, resulting in a generalized operant (Hayes, Barnes-Holmes, \& Roche, 2001; Hughes \& Barnes-Holmes, 2016a; Törneke, Luciano, \& Valdivia, 2008).

From that theoretical approach, there are two fundamental concepts: the first one is functional equivalence, in which two or more stimuli are functionally equivalent to the extent that they have the same effect on behavior -have similar behavioral functions- (Catania, 2012; Tonneau, 2001). Second, verbal behavior understood from the social interaction contingencies in which, the speaker and the listener have a functional repertoire allowing them to issue a behavioral response linked to specific historical, conventional and situational contexts; thus, rule-governance simple involves behavioral regulation due the effect of an antecedent verbal stimulus (Barnes-Holmes, Finn, McEnteggart, \& BarnesHolmes, 2017; Hughes \& Barnes-Holmes, 2016b).

In that sense, rule-governed behavior (RGB) is understood as the main duty of the rule, the impact that the speaker has upon listener's behavior when giving guidelines or maybe influence him/her in a verbal manner (Peláez \& Moreno, 1998). Skinner (1966) referred about rules as contingencyspecifying verbal discriminative stimuli, because behaviors with similar verbal stimuli have a reinforced response. Likewise, rules are formed predominantly from environmental influencers, such as family, educational background, schooling, and communication media, including language, amongst others. This is in such a way that those rules constitute the verbal context that gives consequences about behaviors, allowing subjects themselves assess and judge their own behaviors from the inclusion of this verbal context (Barnes-Holmes et al., 2017; Kissi et al., 2017).

Hayes, Zettle and Rosenfarb (1989) have proposed a functional distinction between three behavioral types that are governed by rules. These are characterized by being non-directly trained relational operations and therefore, they have abstract character and their functions allow establishing opportunities to contact reinforcement and establish new functions, namely pliance, tracking or 
augmenting (Kissi, Hughes, De Schryver, De Houwer, \& Crombez, 2018). Pliance is a rule-governed behavior under the control of a history of socially mediated consequence, with correspondence between the rule and the relevant behavior. A clear example is when a father tells his son eat your breakfast and the child executes that behavior due to a history of possible socially mediated consequences (reinforce by the father), correspondence between the rule and compliance behavior (Hayes, Gilfford, \& Hayes, 1998; Hughes \& Barnes-Holmes, 2016b).

Tracking refers to a rule-governed behavior under the control of history reinforcement due correspondence between the rule and the way the context is independently of the delivery of the rule. In other words, "this type of rules gives the opportunity so that the behavior falls into the control of natural contingencies" (Wilson \& Luciano, 2002, p. 66). In line with the previous example, to consider the situation a tracking behavior, the child would execute the behavior because he feels well, when compliance it, so this is a consequence consistent with the premise eating is healthy and not the order by a third (Barnes-Holmes et al., 2001).

Lastly, augmenting is a rule-governed behavior under control of relational networking altering the degree in which events work as consequences. This means that it is a rule type that instead of specifying consequences or contingencies, it increases the reinforce value of specified consequences in the rule itself and it is under the control of apparent changes in the ability or capacity of events to work as reinforces or punishments (Hayes et al., 1998; Hughes \& Barnes-Holmes, 2016b). In that way, augmenting is subdivided in two categories: motivate augmenting, which work in temporary alternation of the degree in which previously established consequences act as reinforces or punishment. In addition, there is formative augmenting type, which function consists of establishing efficiency of new consequences (Hayes et al., 1989; Kissi et al., 2017).

Törneke et al. (2008) suggested the existence of four basic reasons why rules could probably not be followed or complied with: (a) if the rule is not within the person's repertoire, a subject could understand the charts or drawings or graphs in a traffic sign. However, to make a good following or compliance, it needs to know the meaning of each of those drawings and colors. (b) If the rule comes from a little credibility source, keeping in mind that the impact of a condition depends on the approach from the listener; therefore, a rule could not have the same impact on a citizen if this is told by a peer or by someone with a citizen hierarchy level. (c) When the rule-reinforcing stimulus is not available, compliance is reduced since the forming or training element is absent. In that sense, whenever a police authority is present, it would be more possible that a driver keeps adequate speed. Finally, (d) whenever the rule itself is poor, few elaborated, incoherent or contradictory with the story and knowledge of the listener, probably this rule will not be followed.

Experimentally, Gómez-Becerra, López-Martín and Moreno (2008) assess the effectiveness of several methods to produce breaking or change of the sensibility patterns to the contingencies. They found that the use of contextual request by widening or changes in rules provided, happen to be the most effective procedure to break certain levels of insensitivity towards rule contingencies. The mentioned authors concluded that resistance to extinction was the result to the strengthening of correspondence between the rule and what finally happened as a product of a story of reinforcement; in other words, due a rule-governed behavior tracking type. As an alternative was stated that insensibility could be presented as a consequence of a control on the rule because it was an experimental context. This involves also the role exercised by social desirability also guides to new to a possible rule-governed behavior pliance type, as a response to the resistance presented before the contingency extinction. In agreement to the afore stated, O'Hora, Barnes- Holmes and Stewart (2014) found that in presence of a hierarchical authority, it would be more possible there is compliance, given the fact that if the presented rules are not fulfilled or followed, it is highly likely the presence of a punishment. On the other hand, if the authority figure is a peer, or someone with a similar level (nonhierarchical), the breaking of the rule could be reinforced instead. In experiential level, those investigators also recognized the existence of a very important interference, where to understanding and reception levels the subject has towards pliance type rules to compliance those. 
From another approach, when there is following instructions, Pérez, Dutra dos Reis and de Souza (2009) reported that such a behavior could be kept now there is a correspondence between instructions and reinforcement contingencies. In this way, that behavior under control of instructions could be kept without alterations, although there could be discrepancies between instructions and contingencies. For this reason, the conclusion was that such a maintenance or keeping the rules could occur now, when the response is controlled by describing precedent stimuli to such rule, and not due to the descriptions of several consequences for specified behaviors in instructions or directions.

Likewise, Donadeli and Strapasson (2015) conducted a research with university students, which they wanted know about the relevance of social consequences for following instructions. Such research focused on situations where execution of expected behaviors could be followed by a reinforcement. They found that the existence of an authority agent during the task execution has interference and raises changes in behaviors on following the rules, and clarified that presence is not enough to keep following instructions. In the same way, Pérez, Martinez and Silva (2009) examined the efficiency of training in conditional discriminations to establish pro-social rules of augmenting-formative type. In this case, they found that such training has a positive influence in establishing abstract behavioral functions, being that after making a training session on pro-social behaviors with this typology, there was an increase in expected behaviors.

Based on the above, it would be possible pose that individual behaviors in normative and institutional environments (family, educational, media, and other language mediated contexts), these are regulated by rules and controlled by several reinforcement stories in their particular ontogeny (Hughes \& Barnes-Holmes, 2016b). Likewise, it would be possible wonder if communication strategies, prevention and intervention in a specific context - such as pedestrian traffic - could be grounded within conceptual categories and on accumulated empirical evidences around rule-governed behaviors, with the purpose of improving its effectiveness. This study, therefore, sought to determine the effects of three training types in rule-governed behaviors (pliance, tracking and augmenting) on following, compliance or transgression of pedestrian traffic rules, exploring additionally of gender and preference differences in compliance rules by participants.

\section{Participants}

\section{Method}

Through a non-probability sampling, 231 university students between the ages of 18 and 29 years old were selected, and randomly divided into three experimental groups within a longitudinal design of repeated measures with comparisons between groups (Trigo \& Martínez, 1994; see Table 1). They were all Bogotá residents (129 women and $102 \mathrm{men}$ ), and belonged to business management, law, engineering and psychology undergraduate programs in two private universities.

Participation was voluntary, informed and consent through a form of personal, social and demographic data collection, which additionally presented procedural and ethical conditions of this research. Each and all the participants individually signed those forms. This is pursuant to the national and international ethical regulatory framework (Ministry of Health of Colombia, 1993; Congress of the Republic of Colombia, 2006; American Psychological Association, 2017, 2018). 
Table 1

Experimental design

\begin{tabular}{|c|c|c|c|c|c|}
\hline & $\begin{array}{l}\text { Phase } 1 \\
10 \text { trials }\end{array}$ & $\begin{array}{l}\text { Phase } 2 \\
10 \text { trials }\end{array}$ & $\begin{array}{l}\text { Phase } 3 \\
20 \text { trials }\end{array}$ & $\begin{array}{l}\text { Phase } 4 \\
10 \text { trials }\end{array}$ & $\begin{array}{l}\text { Phase 5 } \\
10 \text { trials }\end{array}$ \\
\hline $\begin{array}{c}\text { Group } 1 \\
\text { Pliance } \\
n=77\end{array}$ & \multirow{3}{*}{$\begin{array}{l}\text { Pretest 1: } \\
\text { Preference } \\
\text { assessment } \\
\text { (compliance- } \\
\text { transgression) }\end{array}$} & \multirow{3}{*}{$\begin{array}{c}\text { Pretest 2: } \\
\text { Preference } \\
\text { assessment: } \\
\text { Compliance } \\
\text { (pliance- } \\
\text { tracking- } \\
\text { augmenting) / } \\
\text { transgression }\end{array}$} & $\begin{array}{l}\text { Training } \\
\text { pliance }\end{array}$ & \multirow{3}{*}{$\begin{array}{l}\text { Post-test 1: } \\
\text { Preference } \\
\text { assessment: } \\
\text { compliance } \\
\text { (pliance- } \\
\text { tracking- } \\
\text { augmenting) / } \\
\text { transgression }\end{array}$} & \multirow{3}{*}{$\begin{array}{l}\text { Post-test 2: } \\
\text { Preference } \\
\text { assessment } \\
\text { (compliance- } \\
\text { transgression) }\end{array}$} \\
\hline $\begin{array}{c}\text { Group } 2 \\
\text { Tracking } \\
n=77\end{array}$ & & & $\begin{array}{l}\text { Training } \\
\text { tracking }\end{array}$ & & \\
\hline $\begin{array}{c}\text { Group } 3 \\
\text { Augmenting } \\
\mathrm{n}=77\end{array}$ & & & $\begin{array}{c}\text { Training } \\
\text { Augmenting }\end{array}$ & & \\
\hline Measures & $\begin{array}{c}\text { Proportion } \\
\text { compliance- } \\
\text { transgression }\end{array}$ & $\begin{array}{l}\text { Proportion } \\
\text { election }\end{array}$ & $\begin{array}{l}\text { Number of } \\
\text { errors }\end{array}$ & $\begin{array}{l}\text { Proportion } \\
\text { election }\end{array}$ & $\begin{array}{c}\text { Proportion } \\
\text { compliance- } \\
\text { transgression }\end{array}$ \\
\hline
\end{tabular}

\section{Experimental tasks and procedure}

The application of experimental task was carried out during 12 group sessions with 21

participants each one, in a noise-isolated room with 36 independent computers appointed individually for each participant. One of the researchers orally provided general instructions about the experimental task and execution, and delivered a written informed consent format at the beginning of each session, so participants signed before starting the training. The app to develop was an SPA (Single Page Application), with AngularJS through Javascript software. Final database was used as an engine from a Node JS server, which was stored in Amazon Web Services with a Linux operative system. This used a PostgreSQL database accessing written information therein with an API REST. Data were collected in real time with this tool.

The experimental task was composed by the following consecutive development phases or stages during two hours approximately (see Appendix for an example of each problem - situation in each phase): screen:

Instruction Phase: The participant logged in to the app platform in which there was a central

Next, several formats will be used for data collection during this research. It has the purpose to find out the daily compliance a pedestrian has on traffic regulations in Bogotá city. Please be honest and answer each question. Remember that this self-report has an important value for this research, since the final goal is have a true reflection on the pedestrian behavior in the city (translated into English).

Afterwards, there was a socio-demographic screen format and the user could access next phase by pressing Start button located in the lower right corner of the screen.

Evaluation Phase 1 (Pretest): The subject entered this stage and in a pop-up window, there was the following screen direction or instruction:

In this format, you will see some situations with which we would like to know what YOUR

EVERYDAY BEHAVIOR as a pedestrian is. Please select the action that you used with more frequency.

During this phase, 10 situations were presented (they were similar for the three experimental groups), in order to assess (without feedback), the compliance or transgression of pedestrian traffic rules by subjects when raising a common city situation. 
There were two possible answer choices. One implying rules-compliance and the other complete transgression. Once the answer was selected by a click, the next situation appeared on screen until total completion of the whole panel and continuance to the next phase.

Evaluation Phase 2 (Pretest): When accessing this stage, there was a pop-up window stating the following instruction:

In this form, you will see a series of situations where you need to select only the one that is most

like THE REASONS by which you behave as you do as a pedestrian.

Ten specific situations were presented (they were the same for the three experimental groups), and they were intended to assess the rule-compliance preferences by each participant concerning the rule governed conduct types (pliance, tracking or augmenting). In each item, there was a problem situation with several single choice possibilities without feedback. Such choices were based on the pedestrian traffic rules and there were four possible choices: Three of following or compliance with pliance, tracking or augmenting type consequences, and one transgression.

Training Phase 3: When logging into this phase, there was the following instruction pop-up screen:

Next, you will be presented with several situations with two possible answer choices. Please select the one that is closer to your FREQUENT behavior as a pedestrian.

Remember to read each statement in detail.

There were 20 items constituted by problem situations based on pedestrian traffic rules with two possible answer choices: compliance or transgression. If a participant selected compliance, there was a verbal-written a direct consequence presented on screen. Such a consequence was pliance, tracking or augmenting type depending on the appointed experimental group. Then, the participant could access next trial. Now, should the person choose the transgression possibility, there was a red color pop up window with a correction sentence. The trial was repeated and number of errors was recorded in selecting until the participant decided and choose the right answer (compliance). Consequence showing time in both cases was 14 seconds in all groups.

Evaluation Phase 4 (Post-test): This stage was composed by the same conditions of evaluation phase 2, but problem situations were presented in a different order.

Evaluation Phase 5 (Post-test): This stage was composed by the same conditions of evaluation phase 1, but problem situations were presented in a different order. After the whole presentation in the phase panel, participants were thanked for their collaboration and researchers committed to return results through e-mail.

For building situations presented in each of the phases, pedestrian traffic rules were taken into account. These are in the Colombian National Traffic Code (Congress of the Republic of Colombia, 2002), and the Positive and Safe Behaviors on the Road Booklet for Pedestrians (District Secretary of Mobility, 2011). Such situations were selected from a reliability analysis performed between 60 possible situations assessed during a pilot application.

\section{Results}

231-participant sample was distributed as follows: 10.4\% ages 18 years old, 59.3\% 19-22 years old, 22.5\% 23-25 years old, and 7.8\% 26-29 years old. In their career, 40\% belonged to marketing studies; $23 \%$ to international business, $14 \%$ studied law; $13.4 \%$ engineering, $4.3 \%$ and $5.2 \%$ belonged to psychology and double program (international businesses and marketing), respectively. Table 2 summarizes age, sex, and career distribution for each experimental group. 
Table 2

Number of participants in each experimental group according to age, sex and career.

\begin{tabular}{|c|c|c|c|c|c|c|c|c|c|c|c|c|c|}
\hline & \multicolumn{6}{|c|}{ Career } & \multicolumn{4}{|c|}{ Age } & \multicolumn{2}{|c|}{ Sex } \\
\hline & & $\mathrm{M}$ & $\mathrm{B}$ & $\mathrm{L}$ & $E$ & $\mathrm{P}$ & $\mathrm{DP}$ & 18- 19 & $19-22$ & $23-25$ & $26-29$ & $\mathrm{M}$ & $\mathrm{F}$ \\
\hline $\begin{array}{l}\text { Group } \\
n=77\end{array}$ & 1 & 31 & 19 & 9 & 14 & 0 & 4 & 6 & 47 & 17 & 7 & 40 & 37 \\
\hline $\begin{array}{l}\text { Group } \\
\mathrm{n}=77\end{array}$ & 2 & 32 & 18 & 12 & 0 & 10 & 5 & 10 & 47 & 16 & 4 & 22 & 55 \\
\hline $\begin{array}{l}\text { Group } \\
\mathrm{n}=77\end{array}$ & 3 & 30 & 16 & 11 & 17 & 0 & 3 & 8 & 43 & 19 & 7 & 40 & 37 \\
\hline
\end{tabular}

M: Marketing; B: International Business; L: Law; E: Engineering; P: Psychology; DP: Double Program. M: Males; F: Females

In evaluation phase 1 , normality and variance homogeneity hypotheses were rejected in the three groups, in relation to compliance choice percentages. When comparing statistic means of that percentages, there were no significant differences neither the three groups $(\chi[2, N=231]=2.32, p=$ $.31)$, nor $\operatorname{sex}(\chi[1, N=231]=2.96, p=.08)\left(M_{\text {mals }}=45.2 ; M_{\text {femeles }}=40.0\right)$. In all groups there were significant differences between the statistical means of percentages related to compliance choice, and those corresponding to transgression (Group 1: $[Z=-2.83 ; p=.00 ; d=.71]$; Group 2: $[Z=-2.19 ; p=.03$; $d=.50]$; Group 3: $[Z=-3.70 ; p=.00 ; d=.92])$. These data would allow to state that those three groups presented homogeneity in preferences for compliance the rules. In those three groups, the compliance choice was always higher than transgression and there were no differences of sex concerning such preferences (see Table 3).

Table 3

Descriptive statistics according to phase and groups

\begin{tabular}{|c|c|c|c|c|c|c|c|}
\hline \multicolumn{8}{|c|}{ Evaluation Phases 1 and 2 (Pretests) } \\
\hline & \multicolumn{2}{|c|}{ Phase 1} & \multicolumn{5}{|c|}{ Phase 2} \\
\hline & Co & $\mathbf{T r}$ & CoP & CoT & CoA & CoTo & $\mathbf{T r}$ \\
\hline Group 1 & $M=58.57$ & $M=41.43$ & $M=24.94$ & $M=43.38$ & $M=19.74$ & $M=88.05$ & $M=11.94$ \\
\hline Pliance & $S D=24.15$ & $S D=24.15$ & $S D=16.67$ & $S D=18.53$ & $S D=15.64$ & $S D=12.46$ & $S D=12.46$ \\
\hline Group 2 & $M=54.81$ & $M=45.19$ & $M=26.23$ & $M=40.26$ & $M=21.17$ & $M=87.66$ & $M=12.33$ \\
\hline Tracking & $S D=19.03$ & $S D=19.03$ & $S D=18.14$ & $S D=18.28$ & $S D=13.76$ & $S D=12.96$ & $S D=12.96$ \\
\hline Group 3 & $M=59.74$ & $M=40.26$ & $M=32.21$ & $M=37.27$ & $M=18.44$ & $M=87.92$ & $M=12.07$ \\
\hline Augmenting & $S D=21.08$ & $S D=21.08$ & $S D=18.61$ & $S D=19.16$ & $S D=12.88$ & $S D=13.60$ & $S D=13.60$ \\
\hline \multicolumn{8}{|c|}{ Evaluation Phases 4 and 5 (Post-tests) } \\
\hline & \multicolumn{2}{|r|}{ Phase 5} & \multicolumn{5}{|c|}{ Phase 4} \\
\hline & Co & Tr & CoP & CoT & CoA & CoTo & $\mathbf{T r}$ \\
\hline Group 1 & $M=74.45$ & $M=24.15$ & $M=27.79$ & $M=36.49$ & $M=27.14$ & $M=91.42$ & $M=8.57$ \\
\hline Pliance & $S D=20.80$ & $S D=20.80$ & $S D=14.20$ & $S D=17.07$ & $S D=15.03$ & $S D=10.22$ & $S D=10.22$ \\
\hline Group 2 & $M=71.56$ & $M=28.44$ & $M=27.27$ & $M=38.70$ & $M=23.37$ & $M=89.35$ & $M=10.64$ \\
\hline Tracking & $S D=21.82$ & $S D=21.82$ & $S D=14.01$ & $S D=17.49$ & $S D=13.43$ & $S D=13.11$ & $S D=13.11$ \\
\hline Group 3 & $M=79.22$ & $M=20.78$ & $M=29.74$ & $M=34.67$ & $M=28.18$ & $M=92.59$ & $M=7.40$ \\
\hline Augmenting & $S D=20.76$ & $S D=20.76$ & $S D=16.93$ & $S D=19.70$ & $S D=16.75$ & $S D=9.78$ & $S D=9.78$ \\
\hline
\end{tabular}


In evaluation phase 2, normality hypothesis was rejected, but variance homogeneity was accepted between the three groups $(p=.34)$. In terms of percentages of choices, it was possible notice a higher trend complies with a rule than transgression. The percentage statistical mean of choices towards compliance increased in relation to prior phase: 88.05 for Group 1, 87.66 for Group 2, and 87.92 for Group 3 (see Table 3). Likewise, when comparing percentage means in compliance, there were no significant differences neither between groups $(\chi[2, N=231]=0.12, p=.94)$, nor $\operatorname{sex}(\chi[1, N=231]=$ $1.46, p=.22)$.

When comparing compliance choice preferences (pliance, tracking or augmenting), inside each group, it was found that Group 1 had significantly higher mean percentages preferences towards tracking option than pliance choice $(Z=-4.53 ; p=.00)$ or augmenting $(Z=-5.47 ; p=.00)$. For Group 2, the finding was the same and kept same comparisons ( $[Z=-4.15 ; p=.00] ;[Z=-5.22 ; p=.00]$, respectively). In Group 3, differences were only found between the mean of tracking choice and pliance choice $(Z=-$ $5.10 ; p=.00)$. In this way, it would be possible state that in the two-pretest phases, each and all the groups presented homogeneous preferences about the compliance/transgression dichotomy. Concerning compliance during evaluation phase 2 , it is true that there was a higher preference for tracking type compliance, and it was homogeneous in the three groups analyzed.

In relation to the number of errors made by the participants during training phase, the normality hypothesis was rejected for the data, but variance homogeneity was accepted between the three groups. Given the fact that they corresponded to independent measures, a comparison between groups was implemented through one-way ANOVA. It was found that there were no differences between error statistical means between the three groups $(F[2,228]=.39, p=.68)$, which indicates that participants made the same average amount of errors. This shows homogeneity in difficulty between groups (Group 1: $M=2.92, S D=1.93$; Group 2: $M=3.01, S D=1.71$; Group 3: $M=3.19, S D=2.16$ ). In the same sense, comparison between sexes in this phase showed no statistical differences $(F[1,23]=3.82, p=.05)$.

In evaluation phase 4 (Post-test), there was a higher percentage in choosing compliance the rule compared to it transgression. No statistical evidence was found allowing state that choice percentages in each group were neither distributed normally and not having variance homogeneity. Comparison between groups allowed state that there were no significant differences between the means of groups $(\chi 2[2, N=$ $231]=1.16, p=.44)$, or $\operatorname{sex}(Z=-.99 ; p=.32)$. Inside each group, the following differences were found in relation to choose preferences for compliance (pliance, tracking or augmenting): For Group 1, choice percentages for tracking type compliance were significantly higher than pliance type choices $(Z=-2.79 ; p$ $=.00)$ and augmenting type choices $(Z=-2.98 ; p=.00)$. In Group 2, the finding was the same and kept the same comparisons $([Z=-3.50 ; p=.00] ;[Z=-4.46 ; p=.00]$, respectively). In Group 3, there were no statistical significant differences.

Finally, the interior description in each study phase, it was found that during posttest evaluation 5, preferences for compliance the rule choices were higher than transgression. In each and all the groups, significant differences were found between the mean of compliance choice percentages, and those corresponding to transgression (Group 1: $[Z=-6.76 ; p=.00 ; d=2.44]$; Group 2: $[Z=-6.17 ; p=.00 ; d=$ 1.97]; Group 3: $[Z=-6.97 ; p=.00 ; d=2.81])$. No significant differences were found neither between the three groups $(\chi[2, N=231]=5.38, p=.07)$, nor sex $(Z=-.78 ; p=.43)$, in relation to the statistical percentage of compliance.

With the goal of identifying the effects per training types in rule-governed behavior in relation to compliance the rule, comparisons were made between evaluation phases in pretest and post-tests. Comparison between evaluation stages 2 and 4 showed the following results: For Groups 1 and 3, percentage mean of compliance choices in evaluation phase 4 was significantly higher than that in evaluation phase $2([Z=-2.73 ; p=.006)] ;[Z=-2.84 ; p=.004]$, respectively). In Group 2, no significant differences were found. When making the same comparisons between evaluation phases 1 and 5 , was found compliance percentages to rule choices were significantly higher in evaluation phase 5 for all the groups $(Z=-5.10 ; p=.00)$, Group $2(Z=-5.63 ; p=.00)$, Group $3(Z=-6.03 ; p=.00)$ (See Figure 1$)$. 

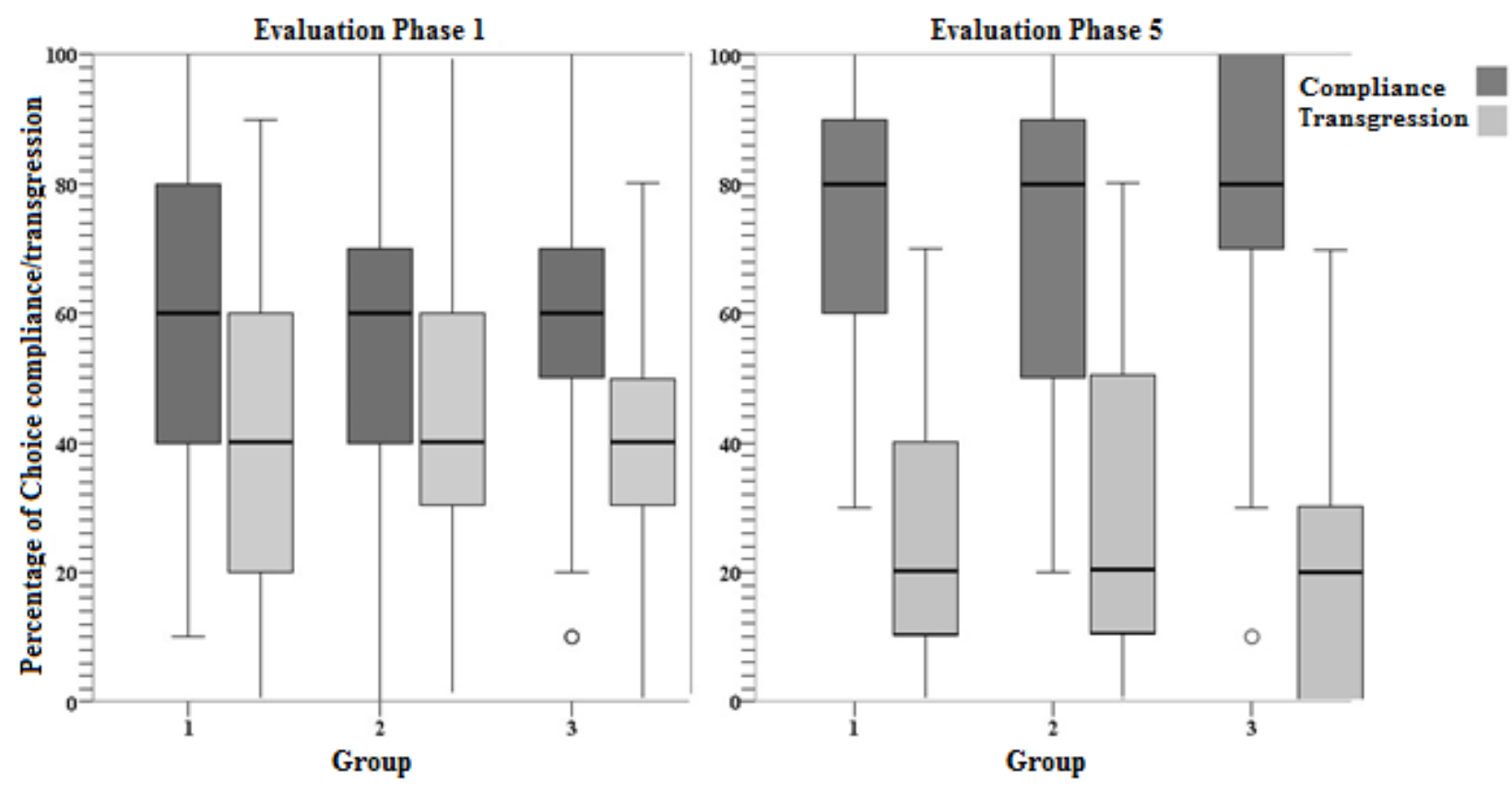

Figure 1. Percentages of choice compliance/transgression in relation to pedestrian traffic rules in evaluation phases 1 (Pretest) and 5 (Post-test).

\section{Discussion}

The aim of the study was to identify the effects of training in three rule-governed behavior types (pliance, tracking o augmenting) concerning compliance or transgress traffic rules for pedestrians. Data show that above-mentioned experimental conditions yielded higher percentages in compliance option to traffic rule in hypothetical problem-situations after training, compared to pretests.

In relation to performance in evaluation phases 1 and 2 (pretests), in which the experimental task was the same for the three groups, there were homogeneous executions between men and women about preference distribution towards compliance or transgression of a traffic rule in problem-situations presented. It is true that in self-report conditions, males stated to have committed transgressions more frequently in relation to pedestrian traffic rules, in comparison to women (Moyano-Díaz, 2002; Yagil, 2000). In addition, accident figures shown by the Legal Medicine and Forensic Sciences Institute (2018) presented a higher amount of male victims (many cases due traffic rule transgression). Similarities between males and females in performing experimental tasks for this research could be an effect to ages of participants. For example, Holland and Hill $(2007,2010)$ was report young male and female adults between 18 and 27 years old tend to have higher probabilities of breaking or not comply the rules, they have more impulsive behaviors and they have higher pedestrian accident rates.

Nonetheless, although statistical means of compliance percentages choices were found significantly higher than transgression, the latter reached an amount of $42.3 \%$, which linked to ages. This result concurs with prior studies that show that young male and female pedestrian and drivers evidence and over-estimation of their skills in traffic situations, and therefore, they assess their risks inadequately (Jiménez-Mejías et al., 2016; Mannocci, Saulle, Villari, \& La Torre, 2019). In fact, they are more prone to break the rule and show risky behaviors (Herrero-Fernández, Macía-Guerrero, Silvano-Chaparro, Merino, \& Jenchura, 2016). As an additional possibility to analyze the absence of differences between sexes in executions in phase 2 of this study, was possible notice that transgression choice percentages in 
the groups evaluated (Males: $M=13.03, S D=12.95$; Females: $M=11.39, S D=12.97$ ), had very low values and a high intra-group dispersion measure. This could have made difficult the fact that differences were clearly expressed in statistics results. Moreover, an increase in proportions for compliance choices between phases 1 and 2 could be because in the latter, there were explicit consequences presented, as derived from one choice or the other. This made an easier contact with the dependence relation between the actions to follow rule, or transgress it, and favorable or unfavorable results from a choice.

In that sense, LeFrancois, Chase and Joyce (1988), Ortiz, Cisneros and Silva (2019), Peláez and Moreno (1998), Pérez et al. (2009) and Villamil, Peña-Correal and Quiroga-Baquero (2018) have described that following or complying with rules is favored by specifications in components that could enter in contingent relationship during a particular problem-situation (stimulus situation, individual response, and consequences).

Another important finding is that in evaluation phase 2, all groups presented a trend to choose compliance the rule with tracking type consequences. This means that before the presentation of problem-situation in a particular trial, participants preferred choose following the rule which consequences corresponded to prevention of unfavorable events or the occurrence of favorable ones under natural occurrence conditions (as disposed by the world, Hughes \& Barnes-Holmes, 2016b; Kissi et al., 2018; Törneke et al., 2008; Zettle \& Hayes, 2016). Such a result allows state that participants showed preferences for choosing following the rule in terms of possible consequences. This is, they give a higher value to natural consequences of following - for instance avoiding accidents and save your own wellbeing and others- and they underestimated social type consequences provided by a third, for instance flattery, or extrinsic rewards to interactive episode of the problem-situation.

A possible explanation to these findings could be to refer to each of the RGB characteristics: Pliance or acceptance is characterized by a reinforcing story mediated by a speaker in correspondence between a rule and a behavior. Such behavioral type is frequent during the first development stages and instruction or training sessions in any environment (Kissi et al., 2017). On the other hand, augmenting types are characterized by being under control of apparent changes in capacity of events to reinforce or punish, keeping similarities with establishment operations (Michael, 1982). These are also frequently used in establishing behavioral repertoires. However, tracking is characterized for being under control of a correspondence between the rule and naturally available contingencies within a particular environment.

In consequence, following or complying with institutionally established rules (e.g., rulings, codes, laws, regulations, etc.), is not going happen due consequences mediated by others, or by the verbal establishment of new consequences, or changes in the value of those. They are going to be followed because of the direct exposure to events allowing avoid unfavorable and risky consequences, or by the occurrence of favorable and successful ones. In that sense, it has been widely reported that whenever there is correspondence between rule contents and programmed contingencies (natural or lab situations), rules do raise or issue a higher and more durable control upon behavior (e.g., Bailey \& Burch, 2017; Buskist, Bennett, \& Miller, 1981; Buskist \& Miller, 1986).

For evaluation phases 4 and 5 (Post-tests), it was noticed that choice percentages regarding compliance the rule increased in comparison to pretests phases in all the three experimental groups. In fact, the effect size ( $d$ Cohen) between compliance choices percentages versus transgression choices percentages in each group is high (almost two standard deviations). The shared characteristic by the three training conditions was that reinforcement contingencies were presented when one of the compliance (or transgression) possibilities were selected, allowing the establishment of RGB repertoires. In that regard, direct exposure to consequences of choice in simulated pedestrian traffic situations, but equal to those frequent in participant's daily lives, allowed the RGB establishment in three types (pliance, tracking and augmenting). These are deemed as response patterns that enter contact with two contingencies: instructional consequences because of compliance, and contingencies that produced what Cerutti (1994) named as collateral consequences, meaning "natural" consequences from a behavior.

From a psycho-legal approach, this research wanted to raise tools for understanding the compliance of traffic regulations by pedestrians since, as Clemente (2012) proposes, this discipline has 
the responsibility of promoting a review on the pertinence of rules and laws. In that way, already described findings would allow identifying three empirical regularities that are applicable to design of rules within the context of traffic and road prevention strategies:

(a) Participants showed preferences for issue and compliance of rules covering natural consequences that are contingent to follow-up or transgression of rules. Thus, road prevention plans could also involve communication, education and rule appropriation processes, explicitly linked to rule compliance behaviors and their consequences under natural scenarios (e.g., through modeling or verbal ways) promoting the formulation of self-rules by citizens. Although the data were obtained from simulated situations in pedestrian traffic (Quiroga-Baquero, Padilla, \& Valerio-dos Santos, 2014), it is possible argue that explanatory mechanisms giving reasons to findings in this research work could be applicable to other traffic contexts, for instance, drivers (Luciano, Valdivia-Salas, Cabello-Luque, \& Hernández, 2009).

(b) Training in RGB yielded an increase in choosing compliance the rule. Behavioral processes linked to establishment and keeping behavioral RGB repertoires, and procedures designed for such a purpose in a laboratory could be translated into natural traffic contexts. This could be achieved by covering the own variables in such an environment, with the purpose of develop effective evidence-based road intervention and prevention programs. Such strategies have been widely adopted in clinical, educational, and organizational contexts, and they all have shown high effectiveness rates (e.g., Backen, Whittingham, Coyne, \& Lightcap, 2016; Clavijo, 2004; Gómez-Becerra, Moreno, \& López-Martín, 2006; López, Muñoz, \& Ballesteros, 2005; Törneke et al., 2008).

As considerations for future research on this topic, it would be possible to assess psychological variables such as personality and intelligence, and also prior participant stories in traffic contexts. This could be carried out thorugh psychometric and questionnaire instruments, since, as pointed out above, they also could play an important role in current individual behavior. In the same line, it is important make comparisons between ages, educational level and other socio-demographic variables that could lead-to additional explanations about the generalization and possible applications of findings. 


\section{References}

American Psychological Association. (2017). Ethical principles of psychologists and code of conduct. Washington, DC: American Psychological Association.

American Psychological Association. (2018). Rules and Procedures - Ethics Committee of the American Psychological Association. Washington, DC: American Psychological Association.

Assaily, J. (2017). Road safety education: What works? Patient Education and Counseling, 100(1), S24S29. doi: 10.1016/j.pec.2015.10.017

Backen, L., Whittingham, K., Coyne, L., \& Lightcap, A. (2016). A contextual behavioral science approach to parenting intervention and research. In R. Zettle, S. Hayes, D. Barnes-Holmes, \& A. Biglan (Eds.), The Wiley Handbook of Contextual Behavioral Science (pp. 398-422). Oxford, UK: Wiley.

Bailey, J., \& Burch, M. (2017). Research Methods in Applied Behavior Analysis. New York: Routledge.

Barnes-Holmes, D., Finn, M., McEnteggart, C., \& Barnes-Holmes, Y. (2017). Derived stimulus relations and their role in a behavior-analytic account of human language and cognition. Behavior Analyst, 41, 155-173. doi: 10.1007/s40614-017-0124-7

Barnes-Holmes, D., O'Hora, D., Roche, B., Hayes, S., Bissett, R., \& Lyddy, F. (2001). Understanding and verbal regulation. In S. Hayes, D. Barnes-Holmes, \& B. Roche (Eds.), Relational Frame Theory: A post-skinnerian account of human language and cognition (pp. 103-117). New York: Kluwer Academic/Plenum Publishers.

Biglan, A. (2016). The need for a more effective science of cultural practices. The Behavior Analyst, 39, 97-107. doi: 10.1007/s40614-016-0051-z

Biglan, A., Zettle, R., Hayes, S., \& Barnes-Holmes, D. (2016). The future of the human sciences and society. In R. Zettle, S. Hayes, D. Barnes-Holmes, \& A. Biglan (Eds.), The Wiley Handbook of Contextual Behavioral Science (pp. 531-541). Oxford, UK: Wiley.

Buskist, W., Bennett, R., \& Miller, H. (1981). Effects of instructional constraints on human fixed-interval performance. Journal of the Experimental Analysis of Behavior, 35, 217-225. doi: 10.1901/jeab.1981.35-217

Buskist, W., \& Miller, H. (1986). Interaction between rules and contingencies in the control of human fixed-interval performance. The Psychological Record, 36, 109-116.

Catania, A.C. (2012). Learning (5 $5^{\text {th }}$ Ed.). New Jersey: Prentice Hall.

Cerutti, D. (1994). Compliance with instructions: Effects of randomness in scheduling and monitoring. The Psychological Record, 44, 259-269. doi: 10.1007/BF03395133

Clavijo, A. (2004). La definición de los problemas psicológicos y conducta gobernada por reglas [The definition of psychological problems and rule-governed benavior]. Revista Latinoamericana de Psicología, 36, 305-316.

Clemente, M. (2012). Papel de las ciencias sociales y del comportamiento en la Ley. Una definición de psicología jurídica [Role of the social sciences and behavior in the Law. A definition of legal psychology]. Psicología Política, 44, 87-107.

Congress of the Republic of Colombia. (2002). Ley 796 de 2002. Por la cual se expide el Código Nacional de Tránsito Terrestre y se dictan otras disposiciones [By which the National Land Transit Code is issued and other provisions]. Retrieved from http://www .alcaldiabogota.gov.co/sisjur/normas/Norma1.jsp?i=5557

Congress of the Republic of Colombia. (2006). Ley 1090 de 2006. Por la cual se reglamenta el ejercicio de la profesión de Psicología, se dicta el Código Deontológico y Bioético y otras disposiciones [By which the exercise of the profession of Psychology is regulated, the Deontological and Bioethical Code is dictated and other dispositions]. Retrieved from http://www.secretariasenado.gov.co/senado/basedoc/ley_1090_2006.html

Congress of the Republic of Colombia. (2011). Ley 1503 de 2011. Por la cual se promueve la formación de hábitos, comportamientos y conductas seguros en la vía y se dictan otras disposiciones [By which it promotes the formation of habits, behaviors and behaviors safe in the way and other 
dispositions are dictated]. Retrieved from http://www.alcaldiabogota.gov.co/sisjur/normas/Norma1.jsp?i=45453

Critchfield, T. (2011). Translational contributions of the Experimental Analysis of Behavior. The Behavior Analyst, 34, 3-17. doi: 10.1007/bf03392227

District Secretary of Mobility. (2011). Comportamientos positivos y seguros en la vía - Peatones [Positive and safe behavior on the road - Pedestrians.]. Retrieved from http://www.movilidadbogota.gov.co/hiwebx_archivos /audio_y_video/Cartilla\%20Peatones.pdf

Donadeli, J. \& Strapasson, B. (2015). Effects of monitoring and social reprimands on instructionfollowing in undergraduate student. Psychological Record, 65, 177-188. doi: 10.1007/s40732014-0099-7

Gómez-Becerra, I., López-Martín, N., \& Moreno, E. (2008). Procedimientos para la ruptura o cambio de la (in)sensibilidad a las contingencias y el control verbal [Rupture procedures for change of insensitivity to contingencies and verbal control]. Revista Latinoamericana de Psicología, 40(3), 441-459.

Gómez-Becerra, I., Moreno, E., \& López-Martín, N. (2006). (In)sensibilidad a unas u otras contingencias en el marco de la conducta gobernada por reglas [Insensitivity to some or other contingencies within the framework of rule-governed behavior]. México: Plaza y Valdez, S.A de CV.

Hayes, S., Barnes-Holmes, D., \& Roche, B. (2001). Relational Frame Theory: A Post-Skinnerian account of human language and cognition. Nueva York: Plenum Press. doi: 10.1007/b108413

Hayes, S., Gilfford, E., \& Hayes, L. (1998). Moral behavior and the development of verbal regulation. The Behavior Analyst, 21, 253-279. doi: 10.1007/bf03391967

Hayes, S., Zettle, R., \& Rosenfarb, I. (1989). Rule following. In S. Hayes (Ed.), Rule-governed behavior: Cognition, contingencies, and instructional control (pp. 191-220). New York: Plenum.

Herrero-Fernández, D., Macía-Guerrero, P., Silvano-Chaparro, L., Merino, L., \& Jenchura, E. (2016). Risky behavior in young adult pedestrians: Personality determinants, correlates with risk perception, and gender differences. Transportation Research Part F: Traffic Psychology \& Behavior, 36, 14-24. doi:10.1016/j.trf.2015.11.007

Holland, C., \& Hill, R. (2007). The effect of age, gender and driver status on pedestrians' intentions to cross the road in risky situations. Accident Analysis and Prevention, 39, 224-237. doi: 10.1016/j.aap.2006.07.003

Holland, C., \& Hill, R. (2010). Gender differences in factors predicting unsafe crossing decisions in adult pedestrians across the lifespan: A simulation study. Accident Analysis and Prevention, 42, 10971106. doi: 10.1016/j.aap.2009.12.023

Hughes, S., \& Barnes-Holmes, D. (2016a). Relational Frame Theory: The basic account. In R. Zettle, S. Hayes, D. Barnes- Holmes \& A. Biglan (Eds.), The Wiley Handbook of Contextual Behavioral Science (129-179). Oxford, UK: Wiley-Blackwell.

Hughes, S., \& Barnes-Holmes, D. (2016b). Relational Frame Theory: Implications for the study of human language and cognition. In R. Zettle, S. Hayes, D. Barnes-Holmes, \& A. Biglan (Eds.), The Wiley Handbook of Contextual Behavioral Science (pp. 179-227). Oxford, UK: Wiley-Blackwell.

International Transport Forum. (2011). Peatones: Seguridad vial, espacio urbano y salud [Pedestrians: Road safety, urban space and health]. Leipzig: Organization for Economic Cooperation and Development. Retrieved from http://www.internationaltransportforum.org/pub/pdf /11PedestrianSumES.pdf

Jiménez-Mejías, E., Martínez-Ruiz, V., Amezcua-Prieto, C., Olmedo-Requena, R., Luna del Castillo, J., \& Lardelli-Claret, P. (2016). Pedestrian- and driver-related factors associated with the risk of causing collisions involving pedestrians in Spain. Accident Analysis \& Prevention, 92, 211-218. doi: 10.1016/j.aap.2016.03.021 
Kissi, A., Hughes, S., De Schryver, M., De Houwer, J., \& Crombez, G. (2018). Examining the moderating impact of plys and tracks on the insensitivity effect: a preliminary investigation. The Psychological Record, 68, 431-440. doi: 10.1007/s40732-018-0286-Z

Kissi, A., Hughes, S., Mertens, G., Barnes-Holmes, D., De Houwer, J., \& Crombez, G. (2017). A systematic review of pliance, tracking, and augmenting. Behavior Modification, 41, 683-707. doi: $10.1177 / 0145445517693811$

Kyonka, E., \& Subramaniam, S. (2018). Translating behavior analysis: a spectrum rather than a road map. Perspectives on Behavior Science, 41, 591-613. doi: 10.1007/s40614-018-0145-x

LeFrancois, J., Chase, P., \& Joyce, J. (1988). The effects of a variety of instructions on human fixedinterval performance. Journal of the Experimental Analysis of Behavior, 49, 383-393. doi: 10.1901/jeab.1988.49-383

Legal Medicine and Forensic Sciences Institute. (2018). Forensis 2017. Datos para la vida [Facts for life]. Bogotá: Imprenta Nacional. Retrieved from http://www.medicinalegal.gov.co/documents/88730/1656998/Forensis+Interactivo+2014.24JULpdf.pdf/9085ad79-d2a9-4c0d-a17b-f845ab96534b

López, A., Muñoz, C., \& Ballesteros, B. (2005). Cambio del contexto social-verbal desde la teoría de marcos relacionales en mujeres en riesgo de desarrollar problemas alimentarios [Changing the social-verbal context from the Relational Frame Theory in women at risk of developing eating problems]. Revista Latinoamericana de Psicología, 37(2), 359-378.

Luciano, C., Valdivia-Salas, S., Cabello-Luque, F., \& Hernández, M. (2009). Developing self-directed rules. In R. Rehfeldt \& Y. Barnes-Holmes (Eds.), Derived Relational Responding Applications for Learners with Autism and Other Developmental Disabilities: A Progressive Guide to Change (pp. 335-353). Oakland, CA: New Harbinger Publications, Inc.

Mannocci, A., Saulle, R., Villari, P., \& La Torre, G. (2019). Male gender, age and low income are risk factors for road traffic injuries among adolescents: an umbrella review of systematic reviews and meta-analyses. Journal of Public Health, 27, 263-272. doi: 10.1007/s10389-018-0932-6

Michael, J. (1982). Distinguishing between discriminative and motivational functions of stimuli. Journal of the Experimental Analysis of Behavior, 37, 149-155. doi: 10.1901/jeab.1982.37-149

Ministry of Heatlh of Colombia. (1993). Resolución 8430 de 1993. Por la cual se establecen las normas científicas, técnicas y administrativas para la investigación en salud [By which establishes the scientific, technical and administrative norms for the investigation in health.]. Retrieved from https://www.minsalud.gov.co/Normatividad_Nuevo/RESOLUCION\%208430\%20DE\%201993.p df

Ministry of Transport of Colombia. (2015). Plan Nacional de Seguridad Vial 2011-2021 [National Road Safety Plan 2011-2021]. Retrieved from http://www .alcaldiabogota.gov.co/sisjur/normas/Norma1.jsp?i=46774

Mockus, A., Murraín, H., \& Villa, M. (Eds.) (2012). Antípodas de la violencia: Desafíos de cultura ciudadana para la crisis de (in)seguridad en América Latina [Antipodes of Violence: Challenges of citizen culture for the crisis of (in) security in Latin America]. New York: Banco Interamericano de Desarrollo.

Moyano-Díaz, E. (2002). Theory of planned behavior and pedestrians' intentions to violate traffic regulations. Transportation Research Part F 5, 169-175. doi: 10.1016/S1369-8478(02)00015-3

Obregón-Biosca, S., Betanzo-Quezada, E., Romero-Navarrete, J., \& Ríos-Nuñez, M. (2018). Rating road traffic education. Transportation Research Part F: Traffic Psychology and Behaviour, 56, 33-45. doi: 10.1016/j.trf.2018.03.033

O’Hora, D., Barnes-Holmes, D., \& Stewart, I. (2014). Antecedent and consequential control of derived instruction-following. Journal of the Experimental Analysis of Behavior, 102(1), 66-85. doi: 10.1002/jeab.95

Ortiz, G., Cisneros, M., \& Silva, L. (2019). Tipo de entrenamiento y momento de elaboración de descripciones poscontacto contingencial en tareas de igualación de la muestra [Training type and 
moment of elaboration of post-contact descriptions in a matching-to-sample task]. Acta Colombiana de Psicología, 22(1), 216-229. doi: 10.14718/ACP.2019.22.1.10

Peláez, M., \& Moreno, R. (1998). A taxonomy of rules and their correspondence to rule-governed behavior. Revista Mexicana de Análisis de la Conducta, 24, 197-214. doi: 10.1037/h0100528

Peña-Correal, T. (2016). El destino del Análisis de la Conducta [The fate of Behavior Analysis]. Acta Comportamentalia, 24(2), 153-168.

Perczek, R. (2013). Inventario de las investigaciones en seguridad vial en Colombia [Road safety researchs inventory in Colombia]. Bogotá: Fondo de Prevención Vial.

Pérez, W., Dutra dos Reis, M., \& de Souza, D. (2009). Ëfeitos de historia experimental com diferentes instruçồ̀s e do controle por contingencias sobre o seguimento de instruçôès [Effects of the experimental history with different kinds of instructions and the control of contingencies for following instructions]. Acta Comportamentalia, 18, 55-85.

Pérez, T., Martinez, A., \& Silva, J. (2009). Establecimiento de reglas prosociales del tipo aumento formativo (augmenting formative) mediante entrenamiento en discriminaciones condicionales [Establishment of prosocial rules of the augmenting-formative type through training in conditional discriminations]. Pensamiento Psicológico, 5, 89-104.

Pérez-Almonacid, R., \& Quiroga-Baquero, L. (2010). Lenguaje: Una perspectiva Interconductual [Language: An interbehavioral perspective]. Bogotá-Colombia: Corporación Universitaria Iberoamericana.

Quiroga-Baquero, L., Padilla, M., \& Valerio-dos Santos, C. (2014). Experimental analysis of the formulation of counterfactual statements in second-order matching-to-sample tasks. European Journal of Behavior Analysis, 15, 149-163.

Rendón-Arango, M. \& Quiroga-Baquero, L. (2017). Investigación traslacional en el estudio de marcos deícticos: reflexiones a partir de un trabajo experimental [Translational research in the study of deictic frames: reflections from an experimental work]. Revista Mexicana de Análisis de la Conducta, 43, 97-127. doi: 10.5514/rmac.v43.i1.61078

Skinner, B.F. (1966). An operant analysis of problem solving. In B. Kleinmuntz (Ed.) Problem solving: Research, method and theory (pp. 133-171). New York: John Wiley \& Sons.

Tonneau, F. (2001). Equivalence Relations: A critical analysis. European Journal of Behavior Analysis, 2, 1-33. doi: 10.1080/15021149.2001.11434165

Törneke, N., Luciano, C., \& Valdivia, S. (2008). Rule-Governed behavior and psychological problems. International Journal of Psychology and Psychological Therapy, 8(2), 141-156.

Trigo, E., \& Martínez, F. (1994). Diseños y procedimientos de validación en la psicología interconductual: discriminación condicional y estrategias longitudinales [Validation designs and procedures in interbehavioral psychology: conditional discrimination and longitudinal strategies]. Revista Mexicana de Análisis de la Conducta, 20, 67-82. doi: 10.5514/rmac.v20.i1.23449

Villamil, C., Peña-Correal, T., \& Quiroga-Baquero, L. (2018). Efectos del contenido funcional de la instrucción sobre el desempeño en igualación a la muestra de segundo orden [Effects of the functional content of instructions on second-order matching-to-sample performance]. Acta Colombiana de Psicología, 21(1), 44-56.

Vollmer, T. (2011). Three variations of translational research: Comments on Critchfield. The Behavior Analyst, 34(1), 31-35. doi: 10.1007/bf03392231

Wilson, K., \& Luciano, C. (2002). Terapia de Aceptación y Compromiso: Un Tratamiento conductual orientado a los valores [Acceptance and Commitment Therapy: A behavioral therapy oriented to values]. Madrid: Pirámide.

Wilson, D., Hayes, S., Biglan, T., \& Embry, D. (2014). Evolving the future: Toward a science of intentional change. Behavioural and Brain Sciences, 34, 395-416. doi:10.1017/S0140525X13001593 
World Health Organization. (2013). Seguridad Peatonal. Manual de seguridad vial para instancias decisorias y profesionales [Pedestrian safety: a road safety manual for decision-makers and practitioners]. Ginebra: World Health Organization. Retrieved from http://apps.who.int/iris/bitstream/10665/128043/1/ 9789243505350_spa.pdf

Yagil, D. (2000). Beliefs, motives and situational factors related to pedestrians' self-reported behavior at signal-controlled crossings. Transportation Research Part F: Traffic Psychology and Behavior, 3(1), 1-13. doi: 10.1016/S1369-8478(00)00004-8

Zare, H., Niknami, S., Heidarnia, A., \& Hossein-Fallah, M. (2019). Traffic safety education for child pedestrians: A randomized controlled trial with active learning approach to develop streetcrossing behaviors. Transportation Research Part F: Traffic Psychology and Behaviour, 60, 734742. doi: 10.1016/j.trf.2018.10.021

Zettle, R., \& Hayes, S. (2016). Rule-governed behavior: A potential theoretical framework for cognitivebehavioral therapy. In S. Hayes (Ed.), The Act in Context. The Canonical Papers of Steven C. Hayes (pp. 7-38). NY: Academic Press. 


\section{APPENDIX}

Examples of statements of problem-situations and possible answer choices in each phase (translating into English)

\begin{tabular}{|c|c|c|c|}
\hline & Phase 1 & Phase 2 & Phase 3 \\
\hline $\begin{array}{l}\text { Problem- } \\
\text { situation } \\
\text { statement }\end{array}$ & $\begin{array}{l}\text { You are reaching a } \\
\text { cross where the } \\
\text { traffic sign for cars } \\
\text { passes to red light } \\
\text { and allows } \\
\text { pedestrians to cross. } \\
\text { In that very } \\
\text { moment, you are } \\
\text { some meters away } \\
\text { from the pedestrian } \\
\text { area to cross, } \\
\text { therefore you: }\end{array}$ & $\begin{array}{l}\text { You are walking with your little } \\
\text { brother to take him to school, and } \\
\text { you know beforehand that on the } \\
\text { way there are speed reducers and a } \\
\text { marked zone as "school zone". } \\
\text { Still, you are far from it. Your little } \\
\text { brother tells you "we better walk to } \\
\text { the cross for pedestrians, so the kids } \\
\text { in the school patrol help us to cross } \\
\text { the street in a faster manner and } \\
\text { with no danger", then you: }\end{array}$ & $\begin{array}{l}\text { You are walking in your } \\
\text { neighborhood with a friend, and you } \\
\text { both reach a vehicle intersection, } \\
\text { where street signs of pedestrian } \\
\text { crossing tell you that in order to } \\
\text { cross, you first need to change your } \\
\text { sidewalk, since traffic signs on the } \\
\text { street where you are currently } \\
\text { walking shall not allow you to cross } \\
\text { in a safe manner. Then, your female } \\
\text { friend tells you: "Let's cross on the } \\
\text { crosswalk, we are safer and we have } \\
\text { no rush at the moment", therefore } \\
\text { you: }\end{array}$ \\
\hline \multirow{9}{*}{$\begin{array}{l}\text { Possible } \\
\text { answer } \\
\text { choices }\end{array}$} & \multirow{7}{*}{$\begin{array}{l}\text { You walk in a rush } \\
\text { to reach the } \\
\text { crosswalk and only } \\
\text { cross on that site. }\end{array}$} & \multirow{2}{*}{$\begin{array}{l}\text { Pliance } \\
\text { Since your Little brother has used } \\
\text { the route during more time, and } \\
\text { knows it better, you obey him and } \\
\text { you cross with him on the school } \\
\text { marked area, and when reaching the } \\
\text { other side of the Street, you say "I } \\
\text { told you it was faster and safer." }\end{array}$} & $\begin{array}{l}\text { Compliance or following choice: } \\
\text { You cross the Street through the } \\
\text { pedestrian area together with your } \\
\text { female friend. }\end{array}$ \\
\hline & & & $\begin{array}{l}\text { Consequence given to Group } \mathbf{1} \\
\text { When crossing the street, your friend } \\
\text { thanks you because during crossing, } \\
\text { there were no accidents. }\end{array}$ \\
\hline & & & Consequence given to Group 2 \\
\hline & & $\begin{array}{l}\text { Tracking } \\
\text { You join a group of people that are } \\
\text { there waiting next to the crosswalk } \\
\text { to cross the Street through the }\end{array}$ & $\begin{array}{l}\text { You both go to the other side of the } \\
\text { street safe and sound, and you both } \\
\text { continued having a conversation. }\end{array}$ \\
\hline & & $\begin{array}{l}\text { school zone, and when doing so; } \\
\text { you notice this is a faster and safer } \\
\text { crossing for everybody. }\end{array}$ & \multirow{3}{*}{$\begin{array}{l}\text { Consequence given to Group } 3 \\
\text { While walking, your female friend } \\
\text { suffered a sprain, but when going on } \\
\text { the sidewalk, they both were able to } \\
\text { reach the other side of the street in a } \\
\text { safe way. }\end{array}$} \\
\hline & & Augmenting & \\
\hline & & $\begin{array}{l}\text { You know that your little brother } \\
\text { has been several times more } \\
\text { through this walking route to } \\
\text { school. Your brother congratulates } \\
\text { you and one of the people in the } \\
\text { school patrol congratulates you } \\
\text { again. }\end{array}$ & \\
\hline & Transgression & Transgression option & Transgression option: \\
\hline & $\begin{array}{l}\text { option } \\
\text { You pass between } \\
\text { cars to cross the } \\
\text { Street, since the } \\
\text { traffic light is red. }\end{array}$ & $\begin{array}{l}\text { Since you are far from the } \\
\text { authorized school zone crossing, } \\
\text { you run to cross the street with your } \\
\text { little brother, so that you leave him } \\
\text { rapidly at school and then you rush } \\
\text { to university. }\end{array}$ & $\begin{array}{l}\text { You cross the street with your friend } \\
\text { by using the point of the sidewalk } \\
\text { where you were walking. }\end{array}$ \\
\hline
\end{tabular}

